TEME, г. XLV, бр. 1, јануар - март 2021, стр. 111-128

Прегледни рад https://doi.org/10.22190/TEME190705007P

Примљено: 5. 7. 2019.

UDK $343.82 ; 343.261$

Ревидирана верзија: 22. 4. 2020.

Одобрено за штампу: 26. 2. 2021.

\title{
ФИЛОЗОФИЈА У ЗАТВОРСКИМ ЗАЈЕДНИЦАМА
}

\author{
Оливера Павићевић*, Љепосава Илијић, Ивана Степановић
}

Институт за криминолошка и социолошка истраживања, Београд, Србија

\begin{abstract}
Апстракт
Промене у казненој политици имају, као део неолибералне управљачке парадигме, политички значај и социјалне последице унутар затворских заједница и изван њих. Затворска популација расте и поред пада или стагнације стопе криминалитета у развијеним земљама, што представља парадокс у коме се огледа стратегија политике неолибералне регулације. Она је повезана са „новом пенологијом”, која у односу на „стару” пенологију, затворску популацију посматра као статистички агрегат који повлачи одређени ризик за остваривање зацртаних управљачких учинака. Унутар затворских заједница одвија се смена из „тврде” моћи у „меку” моћ, те се у раду дискутује о идентитетским и дисциплинским ефектима тог процеса. У том смислу, приказана су искуства истраживања која су филозофију у затворима увела као начин да се оствари индивидуални идентитет раста као подстицај за повратак некадашњих идеја и пракси рехабилитације као психолошког, моралног и социјалног опоравка појединца.
\end{abstract}

Кључне речи: неолиберализам, управљање, затвори, филозофија, идентитет.

\section{PHILOSOPHY IN PRISON COMMUNITIES}

\section{Abstract}

Changes in penal policy which is a part of the neoliberal paradigm have political significance and social consequences within and outside prison communities. The prison population is growing despite the fall and stagnation of the crime rate in developed countries which creates a paradox mirrored in the politics of the neoliberal regulation. It is connected to the "new penology" which unlike the "old" penology sees the prison community as a statistical collective which entails a particular risk for the realization of the set governing goals. Since there is a shift from "hard" to "soft" power within prison communities, this paper discusses the disciplinary effects of this process. It showcases the effects of various projects which have introduced philosophy into prison environments as a way to encourage individual identity growth and inspire the return of practices of rehabilitation as a psychological, moral and social recovery of an individual.

Key words: neoliberalism, governance, prisons, philosophy, identity.

* Аутор за кореспонденцију: Оливера Павићевић, Институт за криминолошка и социолошка истраживања, Грачаничка 18, 11000 Београд, Србија, oliverapavicevic4@gmail.com 


\section{УВОД}

Промене изазване „неолибералним пеналним таласом” (Wacquant, 2010) чине специфичан део комплексне парадигме неолибералног управљања и његове централне тржишне перспективе, која се на плану казнене политике испољила као значајно повећање затворске популације, посебно у САД и УК (Peacock, Turner \& Varey, 2018). Неолиберални казнени удар и промењена затворска популација у Енглеској и Велсу удвостручили су затворску популацију у последњој деценији (85.106 затвореника), с тим да се број затвореника преко 60 година утростручио (Ministry of Justice, 2015). Треба напоменути да се ово повећање броја затвореника догодило у периоду када су стопе криминалитета биле равне или опадајуће (Prison Reform Trust, 2015). Поред законских промена које су довеле до већег броја кажњавања, дошло је и до промене ставова према одређеним врстама криминалитета. То се пре свега односи на „историјско сексуално злостављање”, огромна већина затворених особа су мушкарци, 40\% су сексуални преступници (Peacock, Turner \& Varey, 2018).

Постоје велике варијације у степену у којем је неолиберализам инспирисао нове визије деловања, а конкретан утицај неолибералних идеја је најочигледнији у политичкој сфери, у којој су се изменила преовлађујућа схватања о одговарујућем односу између јавног и приватног сектора (Hall \& Lamont, 2013). Политике стављају нови нагласак на индивидуализацију ризика, одговорности и награде, нова јавност је изградила тржишну конкуренцију у пружању јавних услуга заснованих на праћењу, рангирању и упоређивању (тзв. бенчмаркинг) (Miller \& Rose, 2008). Премда се учинци неолиберализма не могу једнострано оценити ни као монолитини, а ни као потпуно негативни, неоспорно је да је неолиберална реформа имала дубоке ретрибутивне ефекте постајући тежак изазов за одређене друштвене групе.

Неолиберална социјална реструктурација обележена повећањем затворске заједнице, према Ваканту, није одговор на растућу несигурност повезану са криминалом, већ одговор на дифузну социјалну несигурност изазвану фрагментацијом најамног рада и уздизањем етничке хијерархије (Wacquant, 2009). Патерналистичка пенализација има за циљ да контролише и заустави урбане поремећаје изазване економском дерегулацијом и дисциплиновањем несигурне фракције постиндустријске радничке класе (Wacquant, 2010). Марљив и ратоборан „закон и ред” појављују се као исправна и отресита реакција неолиберално оцртаних политика (ширење и уздизање полиција, судова и затвора, пооштравања казнених мера), како у развијеним, „првим друштвима" тако и у постранзиционом друштвима попут Србије. Проузрокујући социјалну несигурност и сходну социјалну беспомоћност, неолиберално дисциплиновање их истовремено разрешава, преводећи социјалне конфликте у криминалне прекршаје владајуће 
нормативности. На тај начин омогућавају политичким елитама да поново потврде ауторитет државе, уједно надокнађујући дефицит легитимности који су давали пореци социјалне и економске заштите, како у кензијанској ери (Wacquant, 2010) тако и у социјалистичким државама. Грађански покрет владавине права у неолибералној владавини постаје „техника за управљање маргиналношћу и жива лабораторија неолиберала" у којој затвор није техничка имплементација за спровођење закона, већ кључни орган држава чији селективни и агресивни распоред у нижим регијама социјалног простора конститутивно штети идеалима демократског грађанства (Wacquant, 2010, стр. 200). Ритуално потврђивање суверенитета државе у уском, театрализованом домену спровођења закона, у чему Вакант види скривену сврху те исте државе - да призна и прикрије своју неспособност да контролише токове капитала (претежно изван граница) - у контексту српског друштва представља покушај да се појачаном пенализацијом зауздају нови и дубоки социјални конфликти настали спровођењем неолибералне социјалне агенде. Оно што им је заједничко јесте дивергенција дијагнозе која социјалну несигурност и анксиозност нижих и средњих слојева преводи у страх и несигурност изазвану нараслим криминалом. Оно што је специфично за Сpбију јесте удружено негативно дејство недовршене декриминилазације друштва као остатка из деведестих година прошлог века, са једне стране, и неолибералне политике појачаних пеналних захтева, са друге стране. Ова два тока наглашавају важност критичке анализе „старих” и „нових” тенденција у пеналним политикама.

Сходно тој потреби, предмет овог рада је упознавање могућности специфичних и релативно нових програма унутар затворских заједница (филозофске дискусије) и дискусија о њима, са освртом на ужи (социологија затвора) и шири друштвени контекст (неолиберална пенална политика). Сложеност интеракције која потиче од различитих извора друштвене и културне динамике која се рефлектује на затворске околности и наративе, као и немогућност да се сви аспекти (економски, политички, социјални, културни, медијски) који се тичу веза између шире друштвене и уже затворске заједнице обухвате једним радом - издвојила је циљ нашег рада. Он је оличен у покушају да се кроз дисциплину филозофије сагледају могућности унутрашње трансформације затвореника и установи да ли су ови програми део биополитичког „дисциплиновања” или могућност одмицања и критичког промишљања како у односу на сопствени идентитет тако и односу на глобални неолиберални идентитет. 


\section{НЕОЛИБЕРАЛНА ЗАТВОРСКА ДИСЦИПЛИНА КАО (НЕ)МОГУЋНОСТ ТРАНСФОРМАЦИЈЕ СОПСТВА}

Помак у политичком вредновању казнене политике важан је и представља само један део дубље промене у концепцији дискурса, циљева и техника казненог процеса (Feeley, 1992, стр. 442). „Нова пенологија" добија менаџерски, а губи трансформативни карактер, који је био својствен „старој пенологији”. Она се не односи ни на кажњавање, а ни на рехабилитацију појединаца; није забринута ни за индивидуално понашање, па чак ни за организацију заједнице, већ је искључиво забринута за процес управљања. Циљ нове пенолошке стратегије није у томе да елиминише криминал, већ да га учини подношљивим кроз систематску координацију (Feeley, 1992, стр. 455).

Неолиберална вештина управљања заснива се на технологији сопства, која подразумева усвајање субјективитета формираног према циљевима и интересима неолиберализма (Rose \& Miller, 1992; Rose, 1999). Управљање се спроводи регулацијом и контролом појединаца, која више није директна, већ почива на подстицању саморегулације, самодисциплине и самокорекције, које су усклађене са циљевима неолибералног управљања (Shore \& Wright, 2011). Неолиберална агенда продире у организовање затворског живота замењујући ауторитарни надзор меком, индиректном и преговарачком регулацијом, која захтева „динамичку безбедност” и „пристојне и стабилне” режиме унутар затворских заједница (Libeling, 2004; Peacock, Turner \& Varey, 2018).

Корпоративна регулација сопства у контексту затворске заједнице представља спровођење неолибералних јавних политика које имају за циљ преобликовање сопства, те затвореника и затворског особља мењајући њихове идентитете и традиционалне улоге и односе. У том смислу, треба имати у виду да је неолиберални пројекат изменио природу односа у затворским заједницама и, као најважније, изменио природу моћи и дисциплинског дискурса. „Реконструкцију моћи” у затворима прати прелазак из „тврде” моћи у „меку” моћ (Crewe, 2009). Затворски службеници су, у све мањој мери, супротстављени затвореницима заузимањем „непријатељске” позиције, која се манифестује „тврдом моћи” (агресија и антагонизам), они постају носиоци „меке моћи”, која функционише са дистанце (Crewe, 2009). Психолошка надмоћ затворског особља потиче од могућности доношења одлука о питањима важним за затворенике (тестирање на дрогу, извештаји који утичу на категоризацију и превремено пуштање на слободу). Мека моћ је без лица и не захтева директну интервенцију особља, а великим делом је заснована на успостављању саморегулације или самодисциплиновања затвореника као нове компоненте затвореничког сопства. Мањак присиле не чини је мање чврстом и ефикасном. Ова „мека сила” кључна је компонента „неопатернализ- 
ма”, који карактерише затворски систем Енглеске и Велса, то је сфера моћи која чини непотребном употребу директне команде или принуде или јој претходи (Crewe, 2009). Преобликовање затвореничког сопства кроз аспекте третмана и регулације остварује се кроз директне односе између особља и затвореника и индиректно кроз политике које подстичу затворенике да регулишу своје понашање, премештајући одговорност за управљање својим понашањем на затворенике који се окрећу позитивном укључивању у режим (Peacock, Turner \& Varey, 2018). Ове политике, неолибералне по свом карактеpy (Garland, 1997), као елемент „владавине” (Dean, 2006; Rose, 1999) обезбеђују затвореницима псеудоанонимни простор, истовремено их оспособљавајући да користе ову аутономију на посебне начине, награђујући их за то. Затвореници се у складу са корпоративним менаџментом „динамичке стабилности” подстичу на интеракцију са особљем мотивисану инструменталним разлозима (Cerwe, 2009). Добар однос са затворским службеником може довести до значајних разлика у смислу добијања мањих услуга, привилегија и позитивних извештаја. Односи су тако мотивисани извештаченошћу личних интереса и експедитивношћу, исто колико и истинским ангажовањем (Ibid.). Динамика доминације почива на ненормативним мотивима одвијајући се у игри моћи различитој у односу на ону која карактерише традиционалну затворску културу.

Кад се затвореници према овој мекој сили не регулишу на одговарајући начин, ауторитарно лице затвора открива се кроз наредбе, контроле и казне о којима затвореници немају простор за преговарање (Cerwe, 2009). Унутар затворске заједнице, од затвореника се очекује да покажу преданост и да се мењају кроз активни ангажман у складу са институционалним циљевима, што не подразумева само пасивно кретање кроз систем, избегавање невоља и поштовање правила, већ и разумевање нејасних критеријума у процени ризика које спроводе затворски службеници (Liebling et al., 1999; Liebling \& Price, 2001; Attrill \& Liell, 2007). Шема заслужених привилегија подстиче затворенике да управљају детаљима свакодневног понашања, које је прилагођено мекој моћи дисциплинских политика, које се по свом домету и својим циљевима разликују од ауторитарнијих стратегија. Оне теже да остваре шири и чвршћи надзор над понашањем и спознајом превазилазећи основне захтеве осигуравања реда и послушности.

„Ауторитарна рехабилитација” (Rotman, 1990), која се остварује унутар меке дисциплине, има значајне последице на пољу слободе, легитимитета и аутономије, јер се ради о институционалној стандардизацији и шематизацији појединачних судбина. Иако организацијски нагласак на међуљудској пристојности и стабилности режима између особља и затвореника, као и смањена ауторитарност, 
барем на површини, даје позитивне ефекте, инструментализација односа између затвореника и особља доводи до њихове извештачености, неаутентичности и неискрености (Cerwe, 2009). Неолиберална пракса моћи и дисциплиновања оличена у афективном менаџменту и корпоративном људском делању заснованом на прорачуну и балансу између савеза, ризика и одговорности (Gershon, 2011) продире у појединачне друштвене сегменте и праксе живота који истовремено представљају могућа места измицања таквом поретку.

\section{ИЗМЕЋУ КРИМИНАЛНОГ И КОНВЕНЦИОНАЛНОГ ИДЕНТИТЕТА}

Сложеност проблема људског идентитета ћемо у сврху наше анализе сузити на питања која се баве идентитетом у специфичном контексту затворске заједнице. Питање сопства и филозофске дилеме шта значи бити човек, у тој ситуацији, подразумевају околности лишавања слободе. Међутим, једно од основних питања које се односи на идентитет личности која је починила криминал тиче се мотивације учиниоца да почне да размишља о идентитету и животу без криминала. Различите криминолошке теорије, а посебно теорије о одустајању (desistence), разматрају идентитетске трансформације као пут у некриминалну будућност учиниоца. Постоје различити одговори који се односе на различите димензије сложеног конструкта идентитета и сопства, као што су вредности, циљеви, хумано деловање и осећање себе. Они су у корелацији са структуралним карактеристикама ширег окружења, али и ужег окружења унутар саме затворске заједнице. Криминални идентитет не чини свеобухватно сопство учиниоца, већ се појављује као један од понуђених идентитета који може бити привремен и смењивати се другим идентитетским димензијама сопства учиниоца. Сваки од тих идентитета „вреднује одређене линије деловања" и мотивише понашање у различитим ситуацијама (Burke \& Reitzes, 1991). Рефлексивно и интерпретативно сопство није одређено фиксираним и једноструким идентитетом, већ је динамично, рефлексивно и спремно за промену. Већина људи има вишеструке погледе на себе, а ти вишеструки идентитети организовани су у хијерархију истакнутости (Sryker \& Burke, 2000). Oceћање сопства у садашњости може бити сплет више централних или суштинских аспеката сопства који су „хронично доступни”, а присуп компоненти самоспознаје укључује како разумевање себе у садашњости тако и усмереност ка сопству у будућности. „Могуће сопство” може се сагледати као позитивно (жељено) и као негативно (нежељено) (Markus \& Nurius, 1985 према Paternoster \& Bushway, 2009, стр. 1113). Могућа сопства су концепти сопства пројектовани у будућности и састоје се од циљева и тежњи, страхова и зебњи. Они нису 
пука фантазија, већ су повезани са садашњим ја, као и прошлим искуствима, која у великој мери могу бити одређена затворским искуством. Унапређивање осећања сопства веома је важно у околностима вишеструких лишавања какво представља затворска казна, а усмеравање ка могућем позитивном стању сопства представља сложен задатак који је поверен различитим затворским третманима (образовање, психотерапија, рад и др.). Криминолошка литература, посебно новија литература о одустајању (енгл. desistance) - говори о пожељној промени идентитета, која се креће од идентитета преживљавања ка идентитету раста (Liebling \& Arnold, 2004; Haigh et al., 2012; Liebling, 2012; Szifris, 2017). Фундаментално и интенционално померање у осећању личности (Maruna, 2001) оличене у трансформацији идентитета различито су сагледане са становишта друштвених веза и конвенционалних улога, које према једном приступу представљају услов промене (утицај породице, запошљавања, затвора, третмана) (Giordano et al., 2002), док према другом теоријском приступу, промена идентитета претходи социо-структурним променама (промена је изазвана предвиђањем застрашујуће будућности у случају наставка криминалног начина живота) (Paternoster \& Bushway, 2009). Интенционална промена сопства пресудна је за одустајање од криминала, она потиче од првобитне одлуке учиниоца да се промене мењајући осећање себе, мотивисани ,застрашујућим сопством” - оним што особа не жели да постане и тежњом ка промени „исквареног сопства” (Paternoster \& Bushway, 2009). Нада у будућност усмерена је ка реализацији „идеалног сопства”, које је у раскораку са доживљајем „стварног сопства" (Higgins, 1987). Међутим, постоје докази да се може одустати од криминала и без интернализације конвенционалног идентитета (Nugent \& Schinkel, 2016), као и да учиниоци могу наставити са криминалним деловањем упркос позитивном, просоцијалном идентитету и конформистичким вредностима (Liem \& Richardson, 2014). Оно што фундаментално разликује оне који одустану од криминала од оних који упорно опстају у њему - може бити повезано са њиховом способношћу да буду посвећени одустајању, да иду право ка њему са осећањем за људско делање (Burnett, 2013; Liem \& Richardson, 2014).

Основна и свеобухватна теза истраживања могућности трансформације идентитета у затворима почива на претпоставци да онеспособљавајуће окружење у затворским заједницама промовише идентитет преживљавања (хипермушкост мачо-поткултуре), док подстицајно окружење промовише идентитет раста (Liebling, 2012; Szifris, 2017). Ова теза признаје улогу особе као дејственика у формирању и развијању сопственог идентитета уз признавање прилике за саморазумевање, које се сматра важном компонентом личног развоја. Међутим, неолиберална перспектива, такође, користи друштвене односе и стратегије у формирању идентитета и захтева деловање као реф- 
лексивни став и сопство као пројекат који се свесно ствара преко различитих могућих савеза и препрека (Gershon, 2011). Појединци су рефлексивни менаџери својих способности и савеза, они управљају собом преузимајући скуп вештина или особина које су по природи фрагментарне, флексибилне и прилагодљиве. Фрагментарно и неесенцијално својство идентитетског језгра (персоналитија) у Гофмановој многострукости сопства које потиче од вишеструких и краткотрајних улога које се одвијају у континууму социјалних интеракција и променљивих контекста (Goffman, 1969; Collins, 1988) - разликује се од рефлексивног аспекта неолибералног бића које постоји пре партикуларног релационог контекста и које одлучује како ће се појединац повезати са другим људима, институцијама и контекстима (Gershon, 2011). Неолиберално сопство је претходеће, аутономно и друштвено конструисано, оно нуди неједнако партнерство као скуп рефлексивних вештина које субјект развија ступајући у друштвене односе као тржишне савезе (при чему се добровољно одриче одређених аспеката своје аутономије). У том смислу, трансформација сопства као скупа употребљивих вештина и остваривање партнерства у неједнаким позицијама, какво постоји у затворским заједницама у неолибералнокорпоративном духу, није пут ка остваривању идентитета раста, већ искључиво развијање капацитета за преживљавање у контексту неолибералне рационалности.

Подстицајно окружење које омогућава идентитет раста у условима дуготрајног затвора тражи прилику и начине за саморазумевање кроз идентитетски преображај који подразумева више од „способности за самопомоћ" (Brown, 2006, стр. 694) или друге облике неолибералног субјективитета, који је способан да преживи у околностима ризика. Идентитет преживљавања у затворској заједници, у том смислу, повезујемо како са традиционалним концептима хипермушкости тако и са неолибералним рефлексивним самоменаџментом. Насупрот њима, пожељни процес помена идентитетских формација (Shapland et al., 2016) повезан је са идентитетом раста, који је од фундаменталног значаја за одустајање од криминала и сходну промену вредносне самоперцепције важну за живот након издржавања затворске казне. Реч је могућности развоја просоцијалног, позитивног идентитета, који карактерише лични раст и развој заснован на елементима међусобних односа, поверења, добробити и отворености (Szifris, 2017). У том смислу, сложеност конструкта идентитета можемо посматрати кроз два концепта, а то је концепт самопомоћи, који би био показатељ преживљавања, и концепт саморазумевања и саморазвоја, који би био показатељ личног раста и развоја.

Имајући ову разлику у виду, прихватамо закључке истраживања која су показала да однос између жеље за конвенционалним и нормалним животом није пресудна у разликовању преступничког иденти- 
тета од оног који то није (Bottoms \& Shapland, 2011; Burnett, 1992; Farall, 2002; Doekhie \& Van Ginneken, 2019). Ова истраживања показала су да не постоји никаква повезаност између конвенционалних аспирација и криминалног понашања јер и они који одустају и они који настављају са криминалним понашањем изражавају конвенционалне циљеве и у затвору и након пуштања из затвора; конвенционалне тежње које изражавају затвореници често су површне и често су ослоњене на конвенционалне успехе (Farrall, 2002); многи учесници истраживања - и они који су одустали и они који су настављали са криминалним понашањем - нису имали конвенционалне узоре, нити могућности за изградњу конвенционалног идентитета услед недостака друштвеног капитала и могућности за остваривање конвенционалних улога; конвенционалне тежње и криминални животни стил нису међусобно искључиви. Упорни преступници су често били посвећени коришћењу криминалних путева како би постигли и испунили уобичајене улоге (Doekhie \& Van Ginneken, 2019).

Овим налазима оспорене су теорије које сугеришу да улога идентитета и когнитивне трансформације у процесу одустајања значи прихватање конвенционалних аспирација јер оне нису довољне, саме по себи, да обухвате ову промену. Недостатак „доступних скрипата” о томе шта представља спровођење „добре” просоцијалне улоге представљао је један од пресудних проблема у трансформацији идентитета, који упућује на то да конвенционалне тежње морају бити испуњене садржајем који ће бити повезан са истинским разумевањем њиховог значаја за будући идентитет учиниоца, чак и у мање конвенционалним околностима. Налази студије оспоравају неке идеје постојећих теорија одустајања које праве разлику између криминалног и конвенционалног идентитета (Giordano et al., 2002; Maruna, 2001) јер упорни преступници прихватају облик криминалног бића које коегзистира заједно са другим некриминалним идентитетима илуструјући замршену амбиваленцију конвеницоналних тежњи и криминалних активности (Doekhie \& Van Ginneken, 2019). Самојачање као развијање позитивне компоненте могућег сопства које подстиче оптимизам и пружа наду спрам боље будућности може ићи и у супротном правцу, тако што ће самојачање оснажити мрачну и негативну компоненту сопства („мрачни отпор” Ниче, 1994) и стварати слику будућности са снажним осећањем безнадежности. Каква ће бити „мапа пута” зависи од саморегулације сопства (између садашњег и могућег) (Paternoster \& Bushway, 2009), али и самоспознаје и самопромене које ће потиснути страх од себе и за себе, а оцртати оствариво позитивно сопство у будућности.

Када је реч о питању шта је то што затворенику може отворити нове путање, обрасце, циљеве и средства у процесу трансформације сопства ка позитивној промени, нагласак је на разлици између 
идентитета преживљавања и идентитета личног раста. Могућности за саморазвој затвореника повезане су са мером у којој је предвиђено да затвореници проводе време сврсисходно, на конструктиван начин како би развили своје потенцијале, стекли осећај за правац и припремили се за отпуштање (Liebling \& Arnold, 2004). Истински лични развој укључује личну трансформацију у којој се у основи мења самоперцепција и будућа имагинација сопства. Затвор и његова морална устројства (формална и неформална) чине елемент квалитета живота у затвору, који је од изузетног значаја за разумевање ефеката затворског живота на доживљај, конструисање и реконструисање будућег сопства учиниоца. Окружење које омогућава смену идентитета опстанка идентитетом личног раста може се описати као окружење које подстиче самопосматрање, самотумачење, успостављање поверења, обезбеђивање простора за позитивну и просоцијалну интеракцију и развијање интелектуалне климе филозофског истраживања (Szifris, 2017). Филозофија, као предмет и дисциплина, добија нови значај и релевантност за учеснике групних дијалога у којима се развија осећање емпатије и (делимичног) заједништва, као додатна, али важна и различита, супкомпонента терапеутског рада у затворима.

\section{ЗНАЧАЈ ФИЛОЗОФИЈЕ И КРИТИЧКОГ МИШЈЕЬА ИЗВАН ЗАТВОРСКЕ ЗАЈЕДНИЦЕ И УНУТАР ЊЕ}

Према традицији либерализма, образовање је схваћено као нешто што ослобађа човека. Оно је само по себи повезано са концептом аутономије јер омогућава човеку да усмери, то јест одреди, сопствени живот (Winch \& Gingell, 2008, стр. 18). Међутим, није реч о било каквом образовању и, уопште, било каквом знању. Управо критичко мишљење испуњава тај циљ образовања, односно припрема човека за аутономију (Winch, 2006). Као мишљење које се критички односи према свакој претпоставци и свакој датости, оно није условљено и ограничено некаквим задатим оквирима. Оно преиспитује чак и задате оквире размишљања.

Последњих година постоји глобална тенденција да се педагогија трансформише тако да се критичко мишљење уведе у све образовне дисциплине (Thomas, 2010). Заговорници „критичке педагогиje” тврде да критичко мишљење омогућава слободу и увећава капацитет људских способности, а то чини, на пример, тако што расветљава неједнаке односе моћи у друштву и на тај начин пружа методе за отпор против његових репресивних сила (Popkewitz \& Flender, 1999). Критичко мишљење преиспитује и критикује односе моћи отварајући нове перспективе. Ако се пође управо од овог становишта, онда је јасно на који начин критичко мишљење може бити корисно за затворску заједницу. Развијање критичког мишљења требало 
би да омогући појединцима да пронађу квалитетније стратегије идентитетске трансформације у затвору већ самим тим што може да омогући другачији поглед на односе моћи у том окружењу. Критички однос према тим односима моћи ослобађа појединца тако што му омогућава да се измести и своју ситуацију као стање неслободе сагледа са стране. Такође, критичко мишљење може да утиче на „психолошко благостање” затвореника, охрабри „саморефлексију” или развије нове интересе и способности (Szifris, 2018).

Међутим, како уопште треба разумети овај концепт критичког мишљења? Критичко мишљење често се дефинише као једна врста способности (енгл. skill) да се размишља разумски, односно да се чињенице прихватају критички, а не да се оне једноставно усвајају без икаквог преиспитивања. Та дефиниција полази од претпоставке да људи обично не анализирају претпоставке, своје свакодневне обавезе и логику свакодневице, а такође и не постављају питања о разлозима или смислености својих живота (Popkewitz \& Flender, 1999). Смисао критичког мишљења је дакле некаква способност да се користе логични аргументи, да се чињенице проверавају, да се препознају неистините тврдње и неосноване генерализације, као и да се означе непоуздани ауторитети и нејасни концепти (Ibid.).

Ипак, може се расправљати о томе да ли, историјски, идеја критичког мишљења потиче из филозофије античке Грчке (Fisher, 2011), премда се са̂м концепт везује са модерну филозофију. Наиме, са̂м постанак филозофије у античкој Грчкој јесте један дисконтинуитет, велики преокрет са мита на логос, који се дешава управо кроз упитност, постављање проблема и покретање расправа о питањима о којима се до тада није расправљано и вођење дијалога уз коришћење логичних аргумената (Vernan, 1990, стр. 101). У том смислу, критичко мишљење је постављање питања о стварима које су иначе прихваћене као датости и расправљање о појавама које се иначе не доводе у питање. Филозофске мисли предсократоваца, а касније Сократове беседе и дијалози које је забележио Платон - представљају рађање управо те традиције критичког размишљања којој је много касније дат овај назив. Наиме, тек је Џон Дјуи увео и користио концепт „рефлексивно размишљење" да објасни облик размишљања који пажљиво анализира веровања и знања улазећи у њихове темеље и водећи рачуна о последицама које из њих следе (Dewey, 1909, према Fisher, 2011, стр. 2). Потом Едвард Гласер појам рефлексивно размишьљање замењује појмом критичко мишљење и каже да оно представља напор да се веровања и знања преиспитају у светлу доказа који их подржавају, као и последица које из њих следе (Glaser, 1941, према Fisher, 2011, стр. 3).

Управо многе дефиниције саме филозофије полазе од идеје коja је накнадно уобличена у концепт критичког мишљења. Теодор 
Адорно, на пример, каже да је филозофија обавезна да немилосрдно критикује сама себе и назива је „критичка саморефлексија” (Adorno, 2004, стр. 3-4). Финк тврди да се филозофија састоји у „негирању задатих и стављених нам на располагање могућих начина мишљења" и у „обрани од предоџби које се намећу из природног односа човијека спрам свијета" (Fink, 1998, стр. 15). Финк такође каже да филозофија настаје у „негирању непосредности људског понашања према бићу, тиме што управо ту непосредност као такву доводи у питање” (Ibid. стр. 16). Филозофија, дакле, доводи у питање све што је непосредно дато, односно одлази иза датости и одводи мисао на спекулативни ниво. Француски филозоф Жил Делез рекао би да је филозофија креативна дисциплина која ствара појмове, јер појмови који објашњавају ствари или појаве увек морају да буду нови (Deleuze, 1994). Другим речима, уместо да користи већ дате појмове који имају учвршћена значења, филозофија их узима, преиспитује и изнова ствара, то јест, оживљава и трансформише или измишља потпуно нове концепте како би нешто ново рекла о нечему. У том смислу, рећи ће Делез, филозофија заправо није пука контемплација, рефлексија или комуникација, већ она ствара појмове који су потребни за ове акције (Ibid. стр. 6).

Како онда треба схватити корист од филозофије уопште или, конкретно, у контексту затворских заједница? Каква је иначе корист од филозофије? Финк, на пример, каже да „филозофија не користи баш ништа” јер она човека чак ,удаљава од важности свакидашњице у којој се налазе његове дужности, патње и радости, ремети га у сигурности његова опхођења са стварима свијета, баца га у бездан упитности и, дође ли до тога, прибавља му знање с којим не може ништа започети” (Fink, 1998, стр. 18). Међутим, управо та бескорисност филозофије која долази од њене метапозиције - иза стварности, чини се, може имати некакву корист. На пример, истраживања Кристине Сифриз, ${ }^{1}$ која је у затворима у Великој Британији организовала филозофске дебате са затвореницима, показала су управо то. Само практиковање филозофског мишљења представља заправо некакав алат помоћу којег се нешто ипак може започети, и то управо у средини каква је затворска.

Ово истраживање Кристине Сифриз упућује на то да постоји извесна практична корист од примене филозофије или самог „филозофирања”. Она се састоји у томе што отворена дискусија о „неутралним” и апстрактним темама има способност да охрабри „позитивну интеракцију” међу осуђеницима у затворима, али и њихову

1 The Conversation, Teaching Philosophy to Prisoners can Help Transform Macho Prison Culture https://theconversation.com/teaching-philosophy-to-prisoners-can-helptransform-macho-prison-culture-91023, 1. 5. 2019. 
смиреност и спремност да реагују без агресије тиме што ће допринети разумевању, слагању и осетљивости за прихватање другачијих перспектива (Ibid.). Ова ауторка се са правом пита да ли би практиковање филозофије кроз радионице и едукативне програме заправо могло да „трансформише” читаву затворску културу и редукује насиље. Ако ништа друго, њено искуство показало је да само учествовање у оваквим активностима чини да се осуђеници осећају слободније унутар затвора, који је са̂м по себи место лишавања слободе јер припадају елитном кругу у оквиру затворске заједнице и могу слободно да расправљају о питањима друштва, друштвеног уређења, морала и слично. Ту је, дакле, реч о стварању метафизичких зона слободе у оквиру физичких простора чија је намена управо лишавање појединаца њихове слободе заједно са свим осталим људским правима.

Ипак, да ли је већ само то питање о трансформативној и оснажујућој моћи филозофије и образовања уопште део неолибералистичке парадигме о одговорном субјекту који са̂м себе изграђује и са̂м себи помаже? Наиме, неолиберални субјект схваћен је као предузетник (Rose, 1999), који се развија и адаптира (Buchowski, 2001), али и развија отпор према системима моћи, способан да трансформише не само себе већ и систем (Chandler \& Reid, 2016). Када Кристина Сифриз говори о саморазвоју кроз рефлексивне праксе, односно када каже да филозофија доприноси развоју појединца кроз истраживање комплексних и апстрактних тема (Szifris, 2018), она можда говори унутар овог дискурса неолиберализма. Међутим, пошто филозофија као критичко мишљење може да доведе у питање све задате оквире размишљања, она омогућава чак и да се изађе из тог неолибералистичког оквира. Овај начин размишљања омогућава појединцу да се мисли из друге перспективе, односно, изван неолибералистичке идеологије. Самим тим што филозофија доводи у питање постојеће концепте и тачке гледишта, она може критички да се односи према било чему, па и према неолиберализму, који се чини као неизбежан јер представља као некакав „доминантни стил живота” (Couldry, 2010) или чак „етику” (Harvey, 2005), која прожима све аспекте друштва.

Чак и ако се занемари читава идеја „трансформације” затворске културе и замисао о филозофији као некаквој врсти самопомоћи (енгл. self-help) као дериват самог неолиберализма као идеологије, може се рећи да сама дефиниција филозофије као једног рефлексивног пројекта упућује на то да она обезбеђује одређени вид слободе. Наиме, она може субјекта да изведе из позиције неолибералног управљаног (енгл. governed) субјекта управо кроз процес преиспитивања постојећих односа моћи. У том смислу, затвореници који имају шансу да практикују филозофију, односно, критичко мишљење, такође добијају могућност да освајају нове слободне територије унутар неслободних простора, критикују са̂м систем, његове етичке кодексе 
и механизме, па на крају чак и да промене или унапреде функционисање самих затвора. Практиковање филозофије у затворима, дакле, може бити вид пружања отпора који уместо физичке силе користи силу критичког размишљања и логичне аргументације.

\section{ЗАКЉУЧАК}

Промене изазване неолибералним пеналним таласом чине специфичан део комплексне парадигме неолибералног управљања и његове централне тржишне перспективе, која се на плану казнене политике испољила као значајно повећање затворске популације и поред релативно стабилне стопе криминала. Неолиберални конструкт је у сфери казнене политике померио и тежиште интересовања ка индивидуализацији и процени ризичних категорија осуђеника, одговорности и награде, при чему је „нова пенологија” дотадашња усмерења ка ресоцијализацији и поправљању учиниоца заменила мерљивим концептом корпоративног менаџерског управљања (затворским системом, ризичним групама осуђеника и сл.). Корпоративна регулација сопства у контексту затворске заједнице представља спровођење неолибералних јавних политика које имају за циљ преобликовање сопства, затвореника и затворског особља, мењајући њихове идентитете и традиционалне улоге и односе. У том смислу, изменио је природу моћи и дисциплински дискурс из „тврде” моћи непријатељске позиције затворских службеника у „меку” моћ психолошке надмоћи, која функционише са дистанце. Практиковање филозофије у затворским заједницама по узору на модел који су неке западне земље већ примениле могао би се и у Србији показати као конструктиван метод оснаживања осуђеника и њиховог оспособљавања за функционисање у заједници.

\section{ЛИТЕРАТУРА}

Adorno, T. W. (2004). Negative Dialectics. London: Routledge

Bottoms, A. Shapland, J. (2016). „Learning to desist in early adulthood: the Sheffield desistence stydy" in Shapland, S. Farrall \& A. Bottoms, Global Perspectives on Desistance: Reviewing What We Know and Looking to the Future. Oxford: Routledge, 99-125

Brown, W. (2006). „American nightmare: neoliberalism, neoconservitivism, and democratization", Political Theory, 34(6), 690 - 714

Bruke, J., P., Reitzes, C. D. (1991). „An Identity Theory Approach to Commitment“, Social Psychology Quarterly 54 (3), 239

Buchowski, M. (2001). Rethinking Transformation: an Anthropological Perspective on Post-Socialism. Poznan: Wydawnictwo Humaniora

Burnett, R (1992). The Dynamics of Recidivism. Oxford: University of Oxford, Centre for Criminological Research. 
Chandler, D., Reid, J. (2016). The Neoliberal Subject: Resilience, Adaptation and Vulnerability. London: Rowman \& Littlefield

Collins. R. (1988). Theoretical Sociology. San Diego: Harcourt Brace Jovanovich.

Couldry, N. (2010). Why voice matters: Culture and politics after neoliberalism. Los Angeles: SAGE.

Crewe, B. (2009). Soft power in prison: Implications for staff- prisoner relationships, liberty and legitimacy. European Journal of Criminology, 8 (6), 455-468

Dean, M. (2006). Governmentality: Power and Rule in Modern Society, London: Sage Publishing.

Deleuze, G., Guattari, F. (1994). What is Philosophy? New York: Columbia University Press

Doekhie, J., Van Ginneken, E. (2019). "House, bells and bliss? A longitudinal analysis European Journal of Criminology. Available at: https://journals.sagepub. com/doi/10.1177/1477370818819702of conventional aspirations and the process of desistance" (Accessed: 25.05.2019)

Farrall, S (2002). Rethinking What Works with Offenders. Cullompton, Devon: Willan Publishing.

Fink, E. (1998). Uvod u filozofiju (Introduction to Philosophy). Zagreb: Matica hrvatska

Ficher, A. (2013). Critical Thinking: An Introduction, 2nd edition. Cambridge: Cambridge University Press

Foucault, M. (1991). Discipline and Punish. The Birth of the Prison. London: Peregrine Books.

Garland, D. (1997). Governmentality' and the problem of crime: Foucault, criminology, sociology. Theoretical Criminology, 1(2), 173-214.

Gershon, I. (2011). „Neoliberal Agency“, Current Anthropology, 52(4), 537-555.

Giordano, P. C., Cernkovitch, S. A., Rudolph, J. L. (2002). "Gender Crime and Desistance: Toward a Theory of Cognitive Transformation", American Journal of Sociology, 107 (4), 990-1064.

Goffman, E. (1969). Presentations of the Self. Plymouth: Latimer Trend \& Co.

Goffman, E. (1963). Stigma: Notes on the management of spoiled identity. Englewood Cliffs, NJ: Prentice-Hall.

Haigh, R., Harrison, T., Johnson, R., Paget, S., \& Williams, S. (2012). "Psychologically Informed Environments and the "Enabling Environments", Housing, Care and Support, 15(1), 34-42.

Hall, A. P., Lamont, M. (2013). Social Resilience in the Neo-Liberal Era. Cambridge: Cambridge University Press.

Harvey, D. (2005). A Brief History of Neoliberalism, Oxford: Oxford University Press.

Popkewitz, T., Fendler, L. (1999). Critical Theories in Education: Changing Terrains of Knowledge and Politics. London: Routledge

Higgins, E. T. (1987). "Self-discrepancy: A theory relating self and affect", Psychological Review, 94(3), 319

Lamont, M. (2000). The Dignity of Working Men: Morality and the Boundaries of Race, Class and Immigration. Cambridge: Harvard University Press.

Lamont, M. (1992). Money, Morals and Manners; The Culture of the French and the American Upper-Middle Class. Chicago: University of Chicago Press

Liebling, A., Arnold, H. Straub, C. (2011). An Exploration of Staff-Prisoner Relationships at HMP Whitemor: 12 Years On. Cambridge University, Prisons Research Centre. London: National Offender Management Service, Ministry of Justice.

Liebling, A. (2012). Can Human Beings Flourish? London: Prison Phoenix Trust Lecture

Liebling, A. assisted by Arnold, H. (2004). Prisons and Their Moral Performance: A Study of Values, Quality, and Prison Life. Oxford: Oxford University Press 
Liem, M, Richardson, N. J. (2014). The role of transformation narratives in desistance among released lifers. Criminal Justice and Behavior, 41(6), 692-712.

Maruna, S. (2001). Making Good: How Ex-Convicts Reform and Rebuild Their Lives. Washington: American Sociological Society.

Miller, P., Rose, N. (2008). Governing the Present: Administering Social and Personal Life. Cambridge: Polity

Nugent, B, Schinkel, M. (2016). "The pains of desistance". Criminology and Criminal Justice 17(5), 1-17

Paternoster, R., Bushway, S. (2009). "Desistance and the Feared Self: Toward an Identity Theory of Criminal Desistance". Journal of Criminal Law and Criminology, 99(4), $1103-1156$

Peacock, M., Turner, M., Varey, S. (2018). „We Call is Jail Craft: The Erosion of the Protective Discourses Drawn on by Prison Officers Dealing with Ageing and Dying Prisoners in the Neoliberal, Carceral System“. Sociology, 52(6), 1152-1168

Rose, N. (1992). „Governing the Enterprising Self“, The Values of the Enterprise Culture: The Moral Debate, Heelas, P. Morris, P. (ed.). London: Routledge, p. 120-138

Rose, N. (1999). Powers of Freedom: Reframing Political Thought. Cambridge: Cambridge University Press

Rose, N., Miler, P. (1992). „Political Power beyond the State: Problematics of Government", The British Journal of Sociology, 43(2), 173-205

Shapland, J., Farrall, S., Bottoms, A. (2016). "Introduction". In: J. Shapland, S. Farrall, A. (Eds.) Bottoms, Global Perspectives on Desistance: Reviewing What We Know and Looking to the Future. Oxford: Routledge, p. 1-9.

Sheldon, S., Burke, J. P. (2000). "The Past, Present, and Future of an Identity Theory". Social Psychology Quarterly, 63(4), 284-297.

Shore, C., Wright, S. (2011). Policy Worlds: Anthropology and the Analysis of Contemporary Power. New York: Berghahn Books.

Sparks, R., Bottoms, A. E., Hay, W. (1996). Prisons and the Problem of Order. Oxford: Clarendon Press.

Szifris, K. (2017). "Socrates and Aristotle: The role of ancient philosophers in the selfunderstanding of desisting offenders", Howard League for Penal Reform Journal, 56(4), 419-436.

Thomas, I. (2009). "Critical Thinking, Transformative Learning, Sustainable Education, and Problem-Based Learning in Universities". Journal of Transformative Education, 7(3), 245-264.

Vernan, Ž. (1990). Poreklo grčke misli (The Origins of Greek Thought) Novi Sad: Izdavačka knjižarnica Zorana Stojanovića Sremski Karlovci

Wacquant, L. (2010). "Crafting the Neoliberal State: Workfare, Prisonfare, and Social Insecurity”. Sociological Forum, 25(2), 127-220.

Wacquant, L. (2009). Punishing the Poor: The Neoliberal Government of Social Insecurity. Durham/London: Duke University Press.

Winch, C. (2006). Education, Autonomy and Critical Thinking. London: Routledge

Winch, C., Gingell, J. (2008). Philosophy of Education: The Key Concepts. London: Routledge 


\title{
PHILOSOPHY IN PRISON COMMUNITIES
}

\author{
Olivera Pavićević, Ljeposava Ilijić, Ivana Stepanović \\ Institute of Criminological and Sociological Research, Belgrade, Serbia
}

\section{Summary}

A prison sentence as a form of punishment in the sense of a specific (political) response leads us to the question of the importance and purpose of rehabilitation. Rehabilitation appears as an antithesis to the prison sentence so that even when the goals of penal policy in the neoliberal governmentality practices are altered in the way we have shown in this paper, there is a demand not to give up on the idea of rehabilitation.

The neoliberal social restructuring has been marked by the increase of the prison population and it isn't a response to the rising insecurity related to crime, but a response to the diffused social insecurity caused by the fragmentation of wage work and glorification of ethnic hierarchy. The goal of the paternalistic penalisation is to control and stop the urban disorders caused by economic deregulation and disciplining the insecure fraction of the post-industrial work class. Hard-working and militant 'law and order' appear like the righteous and vigorous reaction of the neoliberal policies (expansion and the glorification of the police, court and prison, as well as tightening of the prison measures) in both the developed 'first world' countries and post-transitional societies such as Serbia. By producing social insecurity and social helplessness, the neoliberal disciplining is at the same time resolving them while transforming social conflicts into criminal offences. In this way, they are enabling political elites to reconfirm the authority of the state while compensating the deficit of legitimacy acquired by social and economic protection of the Keynesian era, and in the socialist states (Wacquant, 2010). The citizens' movement of the rule of law under the neoliberal governance is becoming a technique for governing the marginal and the living laboratory of the neoliberals within which the prison is not a technical implementation of laws, but a key organ of states whose selective and aggressive layout in the lower regions of social space is constitutively damaging the ideals of democracy (Wacquant, 2010, p. 200). Ritual confirmation of sovereignty of a state in a narrow theatrical domain of law implementation within which Wacquant sees a hidden purpose of the same state, which is to admit and cover up its inability to control capital flows (mostly beyond borders), becomes an attempt to restrain new and deep social conflicts caused by the neoliberal social agenda in the context of the Serbian society. The divergence of the diagnosis which translates social insecurity and anxiousness of the middle classes into fear and social insecurity caused by the rise of crime is what both of them have in common. In the context of Serbia, there are negative consequences of the unfinished decriminalisation of the society which is the heritage from the 1990s, on the one hand, and the neoliberal vision of the strengthened penal requests on the other. These two streams accentuate the importance of the critical analysis of the 'old' and 'new' tendencies in penal politics.

Considering this specific need, this paper focuses on the discussion about the possibilities of specific new programs within prison communities (philosophical discussions) with a reference to the narrower (sociology of prisons) and wider social context (neoliberal penal policy). The complexity of the interaction stems from different sources of the social and cultural dynamics, which is reflected in prison circumstances and narratives. It is impossible to comprehend all the economic, political, social, cultural and 
media aspects of the ties between wider social and narrower prison community. This paper is an attempt to view the possibilities of the internal transformation of prisoners through the discipline of philosophy and investigate whether these programs are a part of the biopolitical 'disciplining' or a possibility of distancing from the prison community through a critical analysis of one's own identity and the global neoliberal identity. 